\title{
SUSTAINABILITY COST ACCOUNTING - PART 1: A MONETARY PROCEDURE TO EVALUATE THE SUSTAINABILITY OF TECHNOLOGIES IN THE SOUTH AFRICAN PROCESS INDUSTRY
}

\author{
A.C. Brent ${ }^{1,2}$, R.P.G. van Erck ${ }^{1}$, and C. Labuschagne ${ }^{1}$ \\ ${ }^{1}$ Chair of Life Cycle Engineering \\ Department of Engineering and Technology Management \\ University of Pretoria, South Africa \\ alan.brent@up.ac.za \\ ${ }^{2}$ Resource Based Sustainable Development \\ Natural Resources and the Environment, CSIR, South Africa
}

\begin{abstract}
The development and management of new technologies is fundamental to the manufacturing sector as a core operational initiative. Managers of a new technology are increasingly pressurised to consider the economic, environmental, and social impacts associated with the life cycle of the technology (and product) during decision-making - i.e. the overall sustainability of the technology. At present, there is no consensus on a methodology to incorporate externalities - for example, environmental and social impacts at macro-level, for which a company is (typically) not held financially liable - into management practices. This paper introduces the Sustainability Cost Accounting (SCA) procedure, whereby externalities (burdens and benefits) are translated into financial terms to assess the overall sustainability performance of a developed technology in the process industry.
\end{abstract}

\section{OPSOMMING}

' $n$ Sentrale operasionele initiatief van die vervaardigings-industrie is die ontwikkeling en bestuur van nuwe tegnologieë. Bestuurders van nuwe tegnologieë word toenemend onder druk geplaas om die ekonomiese-, omgewings-, en sosiale impakte, wat verwant is aan die lewenssiklus van 'n tegnologie (of produk), in ag te neem tydens besluitneming ten opsigte van die globale volhoudbaarheid van die tegnologie. Op hierdie stadium is daar geen konsensus oor die metodologie wat gevolg moet word om eksterne faktore - bv. omgewings- en sosiale impakte op makrovlak, waarvoor ' $n$ maatskappy tipies nie aanspreeklik gehou word nie - te inkorporeer in die bestuurpraktyk. Hierdie artikel stel die Volhoudbaarheid Kosterekeningkunde (VKR) prosedure voor, waarvolgens die oorgrote volhoudbare prestasie, in terme van eksterne voor- en nadele van 'n ontwikkelde tegnologie, in die prosesindustrie ge-assesseer kan word in finansiële terme. 


\section{INTRODUCTION}

Business (including industry), as one of the three pillars of society (the other two being government and civil society) [1], has a responsibility towards the whole of society to engage actively in the sustainability arena. A company's long-term survival strategy must allow for the incorporation of sustainability into decisionmaking practices [2]. It is therefore imperative that businesses align operational processes with the three objectives of sustainable development [3]: economic, environmental, and social sustainability.

In South Africa, companies are also moving towards a more sustainable approach for internal decision-making processes [4]. However, South African legislation mainly focuses on environmental issues [5]; enforcement of and compliance with governmental legislation is weak; and environmental management is often of low importance to industry [6]. In respect of social sustainability, legislation dealing with social aspects has been tabled; but unlike environmental legislation it does not currently affect South African businesses directly [7]. Compared with developed countries, the South African manufacturing sector is typically lagging behind others in incorporating social aspects of sustainability at various levels within the organisation.

Nevertheless, as the markets of large South African companies expand, and they become multinational companies, stricter legislation and enforcement is faced. The global sustainability pressures, through international trade barriers and the promotion of parent companies, consequently drive South African companies to change management practices and production methods [5]. Assessing potential liabilities and sustainability risks of newly developed technologies is therefore fundamental to the technology management process in South African companies.

\subsection{Identification of measurable indicators to assess the sustainability of technologies in the process industry}

The identification of suitable indicators to measure the impact of an operational activity - for example, a newly developed technology - on the three main sustainability dimensions is dependent on the preferences of the specific assessors and decision-makers of sustainability performances in industry. Two approaches are currently under debate [8]. On the one hand, all impacts could be translated into financial terms - which is often understandable, as decision-makers require reasonable objectivity. On the other hand, it is difficult, if not impossible, to place an economic value on all environmental and social impacts, and a qualitative (and quantitative) method with decision analysis techniques (for example, Multi-Criteria Decision Analysis (MCDA)) could be used for the sake of comprehensiveness.

The former approach has been dealt with extensively, especially with respect to environmental sustainability. For example, an "account of sustainability" has been proposed, which attempts to calculate the additional costs borne by an organisation that has to ensure that a newly developed technology has no detrimental effects on the natural environment at the end of an accounting period [9]. Such approaches have 
been formalised into what are now known as full cost accounting (FCA) [10, 11, 12, $13,14]$ and total cost assessment (TCA) [15] procedures. However, the social aspects of sustainability in these and similar studies are all represented [16].

Based on these established FCA and TCA procedures, this paper introduces a Sustainability Cost Accounting (SCA) procedure to assess the environmental and social impacts of a new technology in the process industry in monetary terms, and therefore the overall sustainability performances of a technology with respect to the "triple bottom-line" [17]. Thereby, sustainability weaknesses and associated improvement possibilities of the assessed technology can be identified. Although the SCA procedure is developed specifically for technology management purposes in the South African process industry, it can be applied to other regions and industry sectors.

The SCA procedure is based on a framework of appropriate criteria to assess the sustainability performances of industry activities, which is described in detail elsewhere [8]. The framework is shown in Figure 1, and is divided into different levels to address the separate aspects of corporate responsibility strategy in terms of sustainability. The sub-criteria (level 4) in the framework that evaluate the performances of an operational initiative (for example, a deployed technology) in terms of the three main dimensions of sustainable development are described in Tables 1 to 3 .

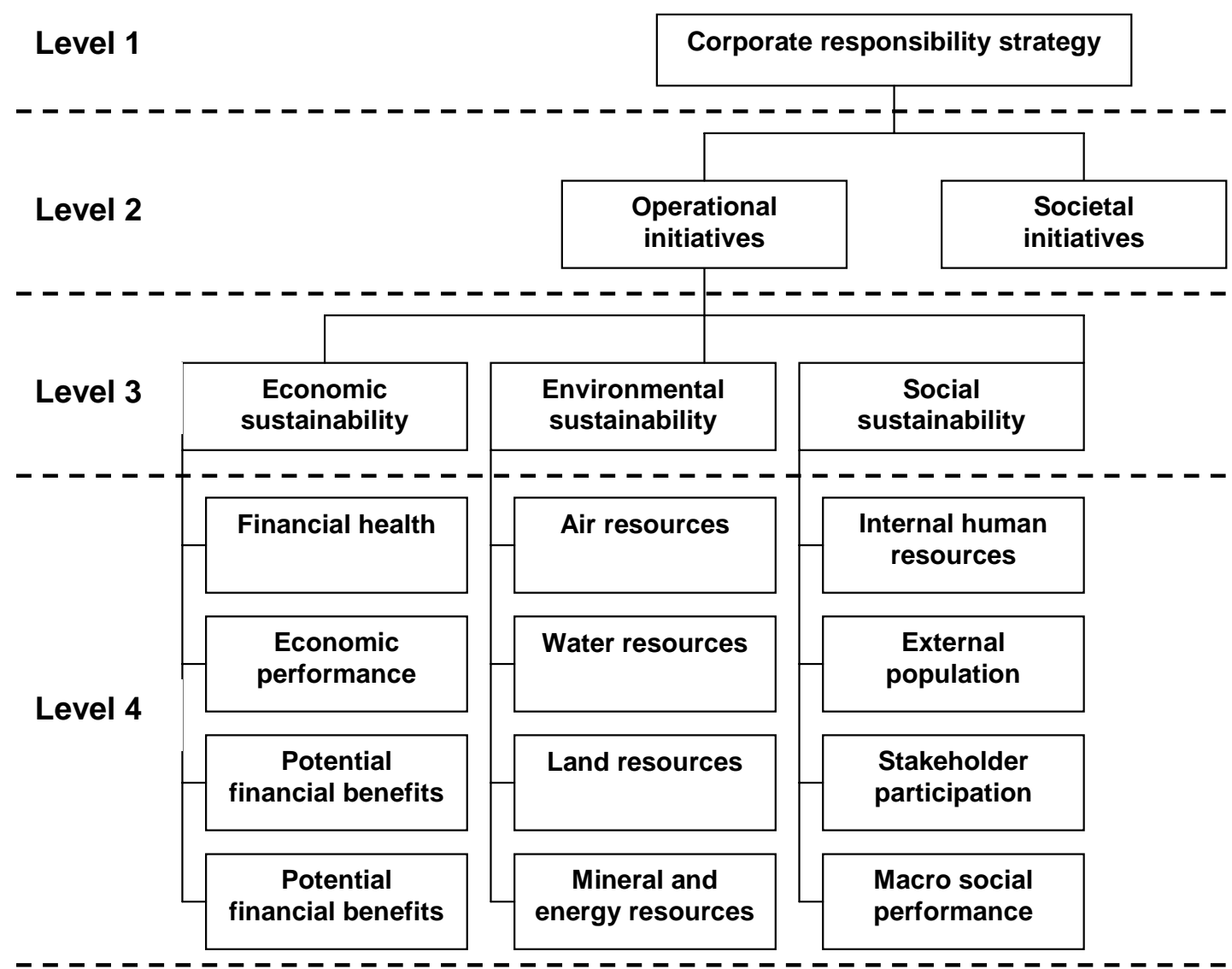

Figure 1: A proposed operational sustainability assessment framework [8] 
Category/Criteria

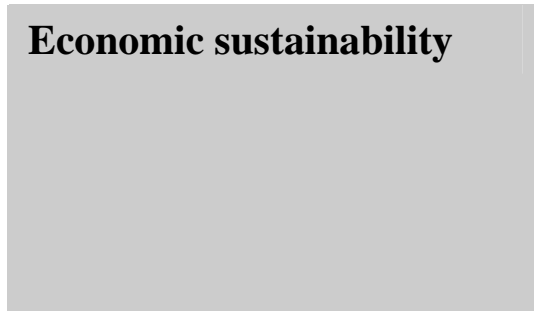

Financial Health

Economic Performance

Potential Financial Benefits

\section{Definition}

The economic dimension concerns the economic health and viability of a developed technology. It has an internal focus that evaluates the organization's short and long-term financial stability and survival capabilities through the introduction of the technology.

Financial Health entails those aspects assessing the internal financial stability of a company (and an introduced technology) and includes traditional measures such as profitability, liquidity and solvability.

Economic Performance assesses the company's value (due to an introduced technology) as perceived by shareholders, top management and government and includes measures such as share profitability, contribution to Gross Domestic Product as well as market share indicators.

Potential Financial Benefits assess financial benefits other than profits (e.g. national and/or international subsidies) based on the environmental, social and/or technological improvements due to an introduced technology.

Trading Opportunities assess the vulnerability of the organization's trade network as well as the risks it is exposed to by the network it is embedded in (due to an introduced technology), by considering the number of national and/or international organizations in the trade network.

Table 1: Definitions of the criteria included in the economic dimension of the framework (Figure 1)

\section{THE SUSTAINABILITY COST ACCOUNTING (SCA) PROCEDURE}

The monetary valuation of sustainability is similar to the methodology of cost-benefit analysis (CBA) in order to internalise, at corporate decision-making level, the externalities associated with an assessed technology (for example, human health impacts on a macro-scale). Thereby, the Sustainability Cost Accounting (SCA) procedure enables trade-offs between costs (external impacts or deterioration in society and the natural environment) and benefits (internal and external contributions). However, differences in the allocation of imposed costs and created benefits make trade-offs problematic from a theoretical perspective, in that trade-offs adhere to the concept of weak sustainability $[18,11]$. Although a company might contribute more than the damage it causes, these contributions do not necessarily 
compensate for the cost of the damage. Therefore, trade-offs between the sub-criteria at level 4 of Figure 1 might be unjustified, and it is recommended that decisionmakers exercise caution when comparing the SCA indicator results and subsequently interpreting the overall sustainability of an assessed technology [19]. Nevertheless, whether addressing environmental or social aspects, sustainability cost accounting adheres to four steps of an economic CBA that have been distinguished [20, 21]:

1. Making an inventory of (positive and negative) impacts on the environment and society as well as on the economic situation of the company.

2. Determination of the monetary value of the impacts.

3. Discounting long-term effects.

4. Assessing risk and uncertainty in case probabilities can be assigned to the likelihood that an event (for example, an industrial accident) will occur, or little is known about future impacts and no probabilities can be assigned.

The fourth step is specific with respect to the evaluated technology and the industry sector. For this reason it is not explicitly addressed in the generalised SCA procedure.

\section{Category/Criteria}

\section{Environmental \\ Sustainability}

Air Resources

Water Resources

Mined Abiotic Resources

Land Resources

\section{Definition}

The environmental dimension concerns an organization's impacts on the environment due to an introduced technology. It has an external focus and addresses impacts on air, water, land, and mined abiotic resources.

Air Resources assess a technology's contribution to regional air quality effects (e.g. visibility, smell, noise levels, etc.) as well as to global effects such as global warming and stratospheric ozone depletion.

Water Resources assess the availability of clean and safe water by focusing on a technology's impacts on the quantity and quality of water.

Land Resources assess a technology's impacts on the quantity and quality of land resources, including aspects such as biodiversity, erosion, transformation and rehabilitation ability, etc.

Mined Abiotic Resources assess a technology's contribution to the depletion of non-renewable mineral and energy resources.

Table 2: Definitions of the criteria included in the environmental dimension of the framework (Figure 1) 


\begin{tabular}{|l|l|l|l|l}
\hline Category/Criteria & Definition \\
\hline Social Sustainability & $\begin{array}{l}\text { The social dimension concerns the technology's } \\
\text { impact on the social systems in which it operates, } \\
\text { as well as the organization's relationships with its } \\
\text { various stakeholders during the development, } \\
\text { operation, and decommissioning of a technology. }\end{array}$ \\
\hline Internal Human Resources & $\begin{array}{l}\text { Internal Human Resources focuses on the social } \\
\text { responsibility of the company towards its workforce, } \\
\text { and includes all aspects of employment (e.g. } \\
\text { employment practices, work conditions, workforce } \\
\text { development, etc.) }\end{array}$ \\
\hline External Population & $\begin{array}{l}\text { External Population focuses on the impact of the } \\
\text { technology on a society, e.g. impact on availability of } \\
\text { services, community cohesion, economic welfare, } \\
\text { etc. }\end{array}$ \\
\hline Stakeholder Participation & $\begin{array}{l}\text { Stakeholder participation focuses on the relationships } \\
\text { between the company and ALL its stakeholders } \\
\text { (internally and externally) by assessing the standard }\end{array}$ \\
\hline $\begin{array}{l}\text { of information sharing and the degree of stakeholder } \\
\text { influence on decision-making. }\end{array}$ \\
\hline Macro Social Performance & $\begin{array}{l}\text { Macro Social Performance focuses on the } \\
\text { contribution of an organization (and its technology) } \\
\text { to the environmental and financial performance of a } \\
\text { region or nation (e.g. contribution to exports). }\end{array}$ \\
\hline
\end{tabular}

Table 3: Definitions of the criteria included in the social dimension of the framework (Figure 1)

\subsection{Inventory of impacts}

In this step, all costs and benefits that are imposed by a company (as a by-product of its economic activity) on third parties are identified. The benefits consider improvements to sustainability, which include the wealth created by a company (through an introduced technology), or the expenditures of a company from which society and the natural environment benefits. The negative impacts concern damage costs, which are the costs associated with the impacts of a technology on the environment and society for which a company is not held (financially) responsible. These externalities have also been referred to as "societal costs" [22].

\subsection{Determining the monetary value of impacts}

Different techniques are available to evaluate externalities, with definite possibilities and limitations to apply to the SCA procedure. However, the techniques have been differentiated between the following $[21,19]$ : 
- "Cost approaches", which assess actual costs or hypothetical expenditures aimed at reducing or eliminating impacts; the two methods that are most often used to establish a range of values for environmental externalities are the damage-cost and the cost-of-control approaches; and

- "Benefit approaches”, which analyse how changes in environmental and social quality affect income or wealth generation in society; one technique that is used is to calculate opportunity costs to preserve an asset (instead of appraising a certain function), e.g. relocating an industrial plant to secure an ecological sensitive area.

For the SCA procedure, published externality cost values from developed countries, based on these two approaches, are adopted for South Africa. Two methods are applied to convert the published data for the South African situation in 2002 with respect to environmental impacts [19]:

- $\quad$ The damage costs to human health that are proposed in international studies are dominated by the valuation of mortality [23]. The single most important parameter is the "value of a statistical life". Assuming that these valuations vary in direct proportion to income, an adjustment is made to the USA and European values to reflect, for example, South African income levels (see Table 4).

- $\quad$ The differences in price levels between countries are used to adapt damage costs of buildings and crops affected by pollutants, and to convert damage costs associated with land use. It is assumed that the relative value of these assets, and the price levels thereof in a given country, reflect the restoration costs. The differences in price levels are shown in Table 5.

\begin{tabular}{|l|l|l|}
\hline Country or Region & $\begin{array}{l}\text { GDP/capita } \\
\text { (US\$) }\end{array}$ & Ratio \\
\hline South Africa & 9.44 & 1.0 \\
\hline United States of America & 35.94 & 3.8 \\
\hline European Union & 24.83 & 2.6 \\
\hline
\end{tabular}

Table 4: GDP/capita ratios (for 2002) of South Africa compared with developed countries or regions [24]

The costs of global environmental impacts associated with a company's emissions do not only affect the area or region where the company is located; the economic estimates of the scale of damage from these pollutants account for global costs, and no adjustment of these values is therefore required for South Africa.

Certain published damage costs are altogether problematic, and have not been used in the SCA procedure. For example, macro socio-economic indicators based on the 
willingness-to-pay approach $[15,20,21]$ have been shown to be unsuitable in the South African context [26].

With respect to social impacts, the actual costs are country-specific, and must therefore be determined on a case-by-case basis.

\begin{tabular}{|l|l|l|}
\hline Country or Region & Price Index $^{\mathrm{a}}$ & Difference $^{\mathrm{b}}$ \\
\hline United States of America & 87.3 & $62 \%$ \\
\hline European Union & 78.7 & $56 \%$ \\
\hline South Africa & 49.0 & - \\
\hline
\end{tabular}

a The Economist Intelligence Unit [25] calculates the costs of living for major cities worldwide. The costs of living are determined by considering the costs of a number of goods and services. The price indexes of fourteen different USA cities and 19 cities in the European Union have been compared to price levels in the cities of Johannesburg and Pretoria in South Africa.

b Difference between price indexes of developed country or region compared with South Africa.

Table 5: Price index of South Africa compared with developed countries or regions [25]

\begin{tabular}{|l|l|l|l|}
\hline $\begin{array}{l}\text { Main } \\
\text { criteria }\end{array}$ & $\begin{array}{l}\text { Sub- } \\
\text { criteria }\end{array}$ & Indicators & Comments \\
\hline $\begin{array}{l}\text { Financial } \\
\text { health }\end{array}$ & $\begin{array}{l}\text { Financial } \\
\text { health }\end{array}$ & Profit after tax & $\begin{array}{l}\text { Estimate figures from annual } \\
\text { (financial) reports }\end{array}$ \\
\hline $\begin{array}{l}\text { Potential } \\
\text { financial } \\
\text { benefits }\end{array}$ & $\begin{array}{l}\text { Potential } \\
\text { financial } \\
\text { benefits }\end{array}$ & $\begin{array}{l}\text { Financial benefits other } \\
\text { than tax reductions } \\
\text { directly related to an } \\
\text { operational initiative }\end{array}$ & $\begin{array}{l}\text { Estimate figures from annual } \\
\text { (financial) reports }\end{array}$ \\
\hline
\end{tabular}

Table 6: The economic indicators that are used in the SCA procedure

\begin{tabular}{|c|c|c|c|c|c|}
\hline $\begin{array}{l}\text { Main } \\
\text { criteria }\end{array}$ & $\begin{array}{l}\text { Sub- } \\
\text { criteria }\end{array}$ & Indicator & Ref & $\begin{array}{l}\text { Cost } \\
(2002)\end{array}$ & Comments \\
\hline Air & $\begin{array}{l}\text { Regional } \\
\text { pollution }\end{array}$ & $\begin{array}{l}\text { Impacts on } \\
\text { human health } \\
\text { (in } \mathrm{R}_{2002} / \mathrm{kg} \text { ) } \\
\text { due to: } \\
\mathrm{SO}_{2} \\
\mathrm{NO}_{\mathrm{x}} \\
\text { Heavy metals }\end{array}$ & $\begin{array}{l}{[29]} \\
{[30]} \\
{[31]}\end{array}$ & $\begin{array}{l}\text { See } \\
\text { Table } 9\end{array}$ & $\begin{array}{l}\text { Based on a population } \\
\text { density of } 80 \\
\text { inhabitants } / \mathrm{km}^{2}\end{array}$ \\
\hline
\end{tabular}




\begin{tabular}{|c|c|c|c|c|c|}
\hline & & $\begin{array}{l}\mathrm{PM}_{10} \\
\text { Photo- } \\
\text { chemical } \\
\text { ozone }\end{array}$ & & & \\
\hline & & $\begin{array}{l}\text { Impacts on } \\
\text { buildings (in } \\
\mathrm{R}_{2002} / \mathrm{kg} \text { ) due } \\
\text { to: } \mathrm{SO}_{2}\end{array}$ & [31] & $\begin{array}{l}\text { R } 2.03 \text { per } \\
\text { kg of } \\
\text { pollutant }\end{array}$ & $\begin{array}{l}\text { Based on a population } \\
\text { density of } 80 \\
\text { inhabitants } / \mathrm{km}^{2}\end{array}$ \\
\hline & & $\begin{array}{l}\text { Impacts on } \\
\text { crops (in } \\
\mathrm{R}_{2002} / \mathrm{kg} \text { ) due } \\
\text { to photo- } \\
\text { chemical } \\
\text { ozone }\end{array}$ & & $\begin{array}{l}\text { See Table } \\
9\end{array}$ & $\begin{array}{l}\text { Based on a population } \\
\text { density of } 80 \\
\text { inhabitants } / \mathrm{km}^{2}\end{array}$ \\
\hline & $\begin{array}{l}\text { Global } \\
\text { pollution }\end{array}$ & $\begin{array}{l}\text { Impacts (in } \\
\mathrm{R}_{2002} / \mathrm{kg} \text { ) due } \\
\text { to greenhouse } \\
\text { gases } \\
\text { (equivalent } \\
\mathrm{CO}_{2} \text { ) }\end{array}$ & $\begin{array}{l}{[31]} \\
{[23]} \\
{[29]}\end{array}$ & $\begin{array}{l}\text { R } 0.22 \text { per } \\
\text { kilogram } \\
\text { of } \mathrm{CO}_{2} \\
\text { equivalent }\end{array}$ & $\begin{array}{l}\text { Damage costs are based on } \\
\text { the lower global estimates } \\
\text { of the European } \\
\text { Commission }\end{array}$ \\
\hline \multirow[t]{2}{*}{ Water } & Water use & $\begin{array}{l}\text { Difference } \\
\text { between } \\
\text { opportunity } \\
\text { costs and } \\
\text { water price }\end{array}$ & $\begin{array}{l}{[32]} \\
{[33]}\end{array}$ & $\mathrm{R} 1.99 / \mathrm{m}^{3}$ & $\begin{array}{l}\text { Estimate based on } \\
\text { difference between } \\
\text { opportunity costs (Van } \\
\text { Horen) and water price } \\
\text { (medium estimate from } \\
\text { Nieuwoudt) }\end{array}$ \\
\hline & $\begin{array}{l}\text { Water } \\
\text { pollution }\end{array}$ & & [15] & Negligible & $\begin{array}{l}\text { Based on willingness to } \\
\text { pay and is considered } \\
\text { negligible }\end{array}$ \\
\hline \multirow[t]{2}{*}{ Land } & Land use & $\begin{array}{l}\text { Opportunity } \\
\text { costs for the } \\
\text { total area } \\
\text { affected }\end{array}$ & [34] & $\begin{array}{l}\text { See Table } \\
10\end{array}$ & $\begin{array}{l}\text { Based on the specific land } \\
\text { type that is affected }\end{array}$ \\
\hline & $\begin{array}{l}\text { Land } \\
\text { pollution }\end{array}$ & Remedy costs & [15] & Negligible & $\begin{array}{l}\text { Based on willingness to } \\
\text { pay and is considered } \\
\text { negligible }\end{array}$ \\
\hline $\begin{array}{l}\text { Mined } \\
\text { abiotic } \\
\text { resources }\end{array}$ & $\begin{array}{l}\text { Minerals } \\
\text { and } \\
\text { energy } \\
\text { resources }\end{array}$ & $\begin{array}{l}\text { Cost of } \\
\text { economic } \\
\text { depreciation } \\
\text { of non- } \\
\text { renewable } \\
\text { resources }\end{array}$ & $\begin{array}{l}{[35]} \\
{[19]}\end{array}$ & $\begin{array}{l}\text { Calculated } \\
\text { user costs } \\
\text { of specific } \\
\text { natural } \\
\text { resources }\end{array}$ & $\begin{array}{l}\text { Discount rate of } 4 \% \text { for } \\
\text { South African setting }\end{array}$ \\
\hline
\end{tabular}

Table 7: The environmental indicators that are used in the SCA procedure 


\subsection{Discounting long-term effects}

Discounting long-term costs and benefits is one of the most widely criticised elements particularly of environmental CBAs [27]. The primary reason is that future environmental costs and benefits have a small impact on the Net Present Value (NPV) of developed technologies. This is advantageous to operational initiatives with long-term environmental impacts and associated costs.

The SCA methodology applies marginal costs of environmental impacts that have been proposed in literature. The discount rates in the published studies apply to different economic regimes, and have to be adjusted to be applicable for South Africa. In general, the discount rates that are used in literature are relatively low - for example, a discount of $2 \%$ has been proposed [28]. These low rates of discount are used, since the growing scarcity of environmental assets will push selling prices upwards and therefore contribute to increasing margins between cost and benefits, thus mitigating the impact of discounting. In contrast, for poorer countries, a discount rate of between $5 \%$ and $8 \%$ has been suggested [27], given the low growth rates and low marginal returns. For a country such as South Africa, with a mixture of first- and third-world conditions, a discount rate of $4 \%$ is adopted for the purposes of this paper. However, it has been shown that small changes in the discount rate can change the results of the SCA assessment substantially [19]; this should be considered during the interpretation of the results, for example through sensitivity analyses. This is addressed in the case studies of part 2.

\section{THE SUSTAINABILITY COST ACCOUNTING (SCA) INDICATORS}

Practicable Sustainability Cost Accounting (SCA) indicators have been proposed [19], based on the theoretical requirements of the SCA procedure (section 2) and the framework to evaluate a developed technology in terms of sustainable development (section 1). The indicators have been developed for the criteria at level 4 of the framework (see Figure 1) and are summarised in Tables 6 to 8. The tables provide the costs of impacts in the South African currency (the Rand (R)) for the year 2002, for direct use in the South African industry. 


\begin{tabular}{|c|c|c|c|}
\hline Main criteria & Sub-criteria & Indicator & Comments \\
\hline \multirow[t]{3}{*}{$\begin{array}{l}\text { Internal } \\
\text { human } \\
\text { resources }\end{array}$} & $\begin{array}{l}\text { Employment } \\
\text { stability }\end{array}$ & $\begin{array}{l}\text { Expenses on: } \\
\text { Wages } \\
\text { U.I.F. } \\
\text { Life insurance } \\
\text { Medical aid }\end{array}$ & $\begin{array}{l}\text { Adopt expenditures from annual } \\
\text { financial reports. Based on } \\
\text { expected number of employees } \\
\text { required to manufacture a product } \\
\text { or provide a service }\end{array}$ \\
\hline & $\begin{array}{l}\text { Health and } \\
\text { safety }\end{array}$ & $\begin{array}{l}\text { Cost (to a } \\
\text { company) of } \\
\text { medical } \\
\text { mortality/mor- } \\
\text { bidity }\end{array}$ & $\begin{array}{l}\text { Damage costs of mortality and } \\
\text { morbidity of employees resulting } \\
\text { from their manufacturing or service } \\
\text { provision activity for a newly } \\
\text { developed technology }\end{array}$ \\
\hline & $\begin{array}{l}\text { Capacity } \\
\text { development }\end{array}$ & $\begin{array}{l}\text { Investments in } \\
\text { training, } \\
\text { education and } \\
\text { R\&D }\end{array}$ & $\begin{array}{l}\text { Adopt expenditures from annual } \\
\text { (financial) reports }\end{array}$ \\
\hline \multirow[t]{2}{*}{$\begin{array}{l}\text { External } \\
\text { population }\end{array}$} & $\begin{array}{l}\text { Human } \\
\text { capital }\end{array}$ & $\begin{array}{l}\text { Investments in } \\
\text { medical and } \\
\text { educational } \\
\text { facilities directly } \\
\text { attributable to an } \\
\text { introduced } \\
\text { technology }\end{array}$ & $\begin{array}{l}\text { Adopt expenditures from annual } \\
\text { reports or project specific } \\
\text { publications }\end{array}$ \\
\hline & $\begin{array}{l}\text { Community } \\
\text { capital }\end{array}$ & $\begin{array}{l}\text { Real estate price } \\
\text { changes in the } \\
\text { area where a } \\
\text { technology is } \\
\text { introduced }\end{array}$ & $\begin{array}{l}\text { Base estimates on real estate prices } \\
\text { provided by local real estate agents } \\
\text { and total real estate value provided } \\
\text { by municipalities }\end{array}$ \\
\hline $\begin{array}{l}\text { Stakeholder } \\
\text { participation }\end{array}$ & $\begin{array}{l}\text { Stakeholder } \\
\text { participation }\end{array}$ & $\begin{array}{l}\text { Expenses on } \\
\text { Environmental } \\
\text { Impact } \\
\text { Assessments }\end{array}$ & Company-specific information \\
\hline \multirow[t]{2}{*}{$\begin{array}{l}\text { Macro-social } \\
\text { performance }\end{array}$} & $\begin{array}{l}\text { Socio- } \\
\text { economic } \\
\text { performance }\end{array}$ & $\begin{array}{l}\text { Tax on profits } \\
\text { Tax on wages } \\
\text { Other taxes }\end{array}$ & $\begin{array}{l}\text { Adopt expenditures from annual } \\
\text { financial reports. Based on } \\
\text { expected profit and number of } \\
\text { employees related to a } \\
\text { manufactured product or provided } \\
\text { service }\end{array}$ \\
\hline & $\begin{array}{l}\text { Socio- } \\
\text { environmen- } \\
\text { tal } \\
\text { performance }\end{array}$ & $\begin{array}{l}\text { Expenditure on } \\
\text { monitoring }\end{array}$ & $\begin{array}{l}\text { Expected investment in regional } \\
\text { pollution monitoring due to the } \\
\text { introduced technology }\end{array}$ \\
\hline
\end{tabular}

Table 8: The social indicators that are used in the SCA procedure 


\begin{tabular}{|c|c|c|c|c|}
\hline Pollutant & Impact & $\begin{array}{l}\text { Costs } \\
(€ / \mathbf{k g})^{\mathrm{a}}\end{array}$ & Reference & $\begin{array}{l}\text { Converted } \\
\text { costs } \\
\text { (Rand/kg) }\end{array}$ \\
\hline $\mathrm{PM}_{10}$ (primary) & $\begin{array}{l}\text { Mortality and } \\
\text { morbidity }\end{array}$ & 15.40 & [23] & 63.80 \\
\hline $\mathrm{SO}_{\mathrm{x}}$ (primary) & $\begin{array}{l}\text { Mortality and } \\
\text { morbidity }\end{array}$ & 0.30 & [23] & 1.24 \\
\hline $\begin{array}{l}\mathrm{SO}_{\mathrm{x}} \text { (via } \\
\text { sulphates) }\end{array}$ & $\begin{array}{l}\text { Mortality and } \\
\text { morbidity }\end{array}$ & 9.95 & [23] & 41.20 \\
\hline $\mathrm{NO}_{\mathrm{x}}$ (primary) & $\begin{array}{l}\text { Mortality and } \\
\text { morbidity }\end{array}$ & Negligible & [23] & - \\
\hline $\mathrm{NO}_{\mathrm{x}}$ (via nitrates) & $\begin{array}{l}\text { Mortality and } \\
\text { morbidity }\end{array}$ & 15.70 & [23] & 65.00 \\
\hline $\mathrm{NO}_{\mathrm{x}}\left(\right.$ via $\left.\mathrm{O}_{3}\right)$ & $\begin{array}{l}\text { Mortality and } \\
\text { morbidity }\end{array}$ & 1.15 & [30] & 4.76 \\
\hline $\mathrm{NO}_{\mathrm{x}}\left(\operatorname{via} \mathrm{O}_{3}\right)$ & Crops & 0.35 & [30] & 2.37 \\
\hline $\operatorname{VOC}\left(\right.$ via $\left.\mathrm{O}_{3}\right)$ & $\begin{array}{l}\text { Mortality and } \\
\text { morbidity }\end{array}$ & 0.73 & [30] & 3.04 \\
\hline VOC (via $\left.\mathrm{O}_{3}\right)$ & Crops & 0.20 & [30] & 1.32 \\
\hline CO (primary) & Cancer & 0.02 & {$[23]$} & 0.08 \\
\hline As & Cancer & 171.00 & [29] & 708.00 \\
\hline Cd & Cancer & 20.90 & [29] & 87.00 \\
\hline $\mathrm{Cr}(\mathrm{VI})$ & Cancer & 140.00 & [29] & 580.00 \\
\hline $\mathrm{Ni}$ & Cancer & 2.87 & [29] & 11.90 \\
\hline
\end{tabular}

a The damage costs assume an average population density of 80 persons $/ \mathrm{km}^{2}$, in 1995 prices.

b The damage costs converted to South African circumstances, in 2002 prices.

Table 9: Damage costs of selected regional air pollutants 


\section{Type of land affected ${ }^{\mathrm{a}}$}

Forests

Grass/rangelands

$$
\text { Wetlands }^{\text {b }}
$$

Lakes/rivers $^{\mathrm{b}}$

Cropland

Urban

Other
Value per hectare (US\$/ha/year), 1997 prices

302.00

232.00

\section{$14,785.00$}

$8,498.00$

\subsection{0}

0.00

0.00

a The value of these specific land types is extremely regionally bound.

b The high damage costs of these affected land types are due to the scarcity of these natural assets in the specific regions where the study was conducted.

Table 10: Damage costs per hectare of selected land use types [34]

\subsection{Attributes of the SCA procedure in terms of the value of company means and assets}

By applying the monetary appraisal to determine a technology's sustainability performance, only those impacts on criteria that are convertible in monetary terms are taken into consideration. These impacts can be divided into two categories:

- $\quad$ The first category results from some of the money flows from and to a company. These money flows are all part of the company's turnover, and some contribute to the sustainability of the company or its operational initiative, such as the profit.

- $\quad$ The second category results from impacts on assets the company does not (directly) pay for. The most important of these (macro) effects are the so-called externalities, such as damage costs from pollution.

Figure 2 illustrates how these different impacts can be linked to corporate financial evaluations. In Figure 2 the bar on the left represents the total value of means and assets over which a company has control. Some of these means are allocated in such a way that they contribute to the sustainability of the company. On the other hand, some of the impacts on assets decline the company's (and evaluated technology's) sustainability. 


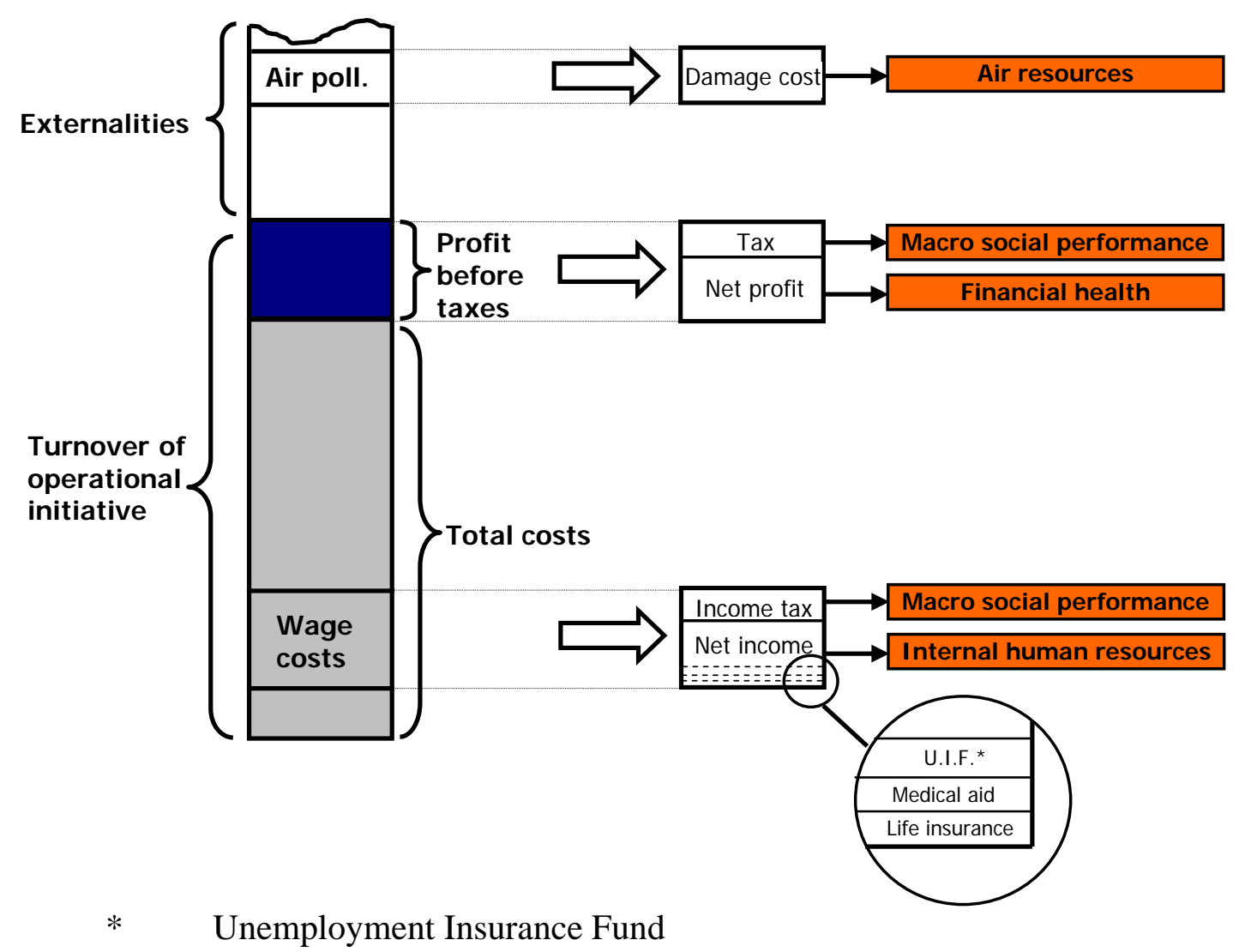

Figure 2: Example of the mechanism used for Sustainable Cost Accounting [19]

An example of allocation of means that contribute to the company's sustainability is the profit from its operations. As shown in the Figure, the profit contributes to different aspects of sustainability. The taxes paid on profit are contributions to the government's budget, which is used to benefit society. These fall under "macro social performance" as part of social sustainability in the framework (see Figure 1). The profit after taxes contributes to the financial health of the operational activity (e.g. a technology) and therefore contributes to the economic sustainability of the company. Another example is the expenditure on wages that is part of the company's costs. These expenditures contribute to the social sustainability of the company's activity. Figure 2 illustrates how different parts of these expenditures are divided in terms of sustainability. As is shown, costs do not necessarily have a negative impact on the result of the SCA of the operational initiative; if these costs are expenses society benefits then from positive effects of these costs are taken into account in the total sustainability assessment.

The bar in Figure 2 represents a value, but gives no indication whether a part of this value has a positive or a negative impact on the company's sustainability. By the translation of parts of this value to the different operational sustainability sub-criteria (level 4 of Figure 1), that distinction is made. 


\section{CONCLUSIONS}

A Sustainable Cost Accounting (SCA) procedure is introduced in this paper (part 1), whereby the external (macro) impacts of an introduced technology can be converted into monetary terms for internal decision-making at company level. The procedure is based on existing Full Cost Accounting (FCA) and Total Cost Assessment (TCA) methods, but due consideration is given to social as well as environmental impacts. This differs from the current approaches. Through the common denominator, the externalities can be incorporated with a typical internal (financial) evaluation of the performance of a technology. The overall sustainability of a technology is ensured thereby - that is, the "triple bottom-line" approach. The SCA procedure identifies which criteria of a comprehensive sustainable development framework are practicable from the perspective of a monetary methodology. Monetary indicators are subsequently proposed for the economic, environmental, and social dimensions of sustainable development. The economic indicators are based on established evaluation methods. The environmental indicators apply costs (of externalities) that have been proposed for other regions in the world. The conversion methodology of these values for other regions (specifically South Africa) is discussed. With respect to the social indicators, new valuation procedures are proposed.

The indicators and the SCA procedure are to be demonstrated and assessed with a specific case study in the South African context - that is, within the South African process industry - in part 2 of this paper.

\section{REFERENCES}

[1] Wartick, S.L. and Wood, D.J. 1998. International business and society, Blackwell, Malden.

[2] Holliday, C.O., Schmidheiny, S. and Watts, P. 2002. Walking the talk: The business case for sustainable development, Greenleaf Publishing, Sheffield.

[3] Keeble, J.J., Topiol, S. and Berkeley, S. 2003. Using indicators to measure sustainability performance at a corporate and project level, Journal of Business Ethics, 44, pp 149-158.

[4] Van der Walt, J. 2003. Personal interview, Sasolburg.

[5] Sampson, I. 2001. Introduction to a legal framework to pollution management in South Africa, Deloitte \& Touche and South African Water Research Commission (WRC) Report, no TT149/01, Pretoria.

[6] Brent, A.C., Rohwer, M.B., Friedrich, E. and von Blottnitz, H. 2002. Overview: LCA in South Africa: Status of Life Cycle Assessment and Engineering research in South Africa, International Journal of Life Cycle Assessment, 7(3), pp 167-172.

[7] Labuschagne, C. 2003. Sustainable project life cycle management: Criteria for the South African process industry, Masters thesis, Department of Industrial and Systems Engineering, University of Pretoria.

[8] Labuschagne, C., Brent, A.C. and van Erck, R.P.G. 2005. Assessing the sustainability performances of industries, Journal of Cleaner Production, 13(4), pp 373-385. 
[9] Gray, R.H. 1992. Accounting and environmentalism: An exploration of the challenge of gently accounting for accountability, transparency and sustainability, Accounting, Organizations and Society, 17(5), pp 399-426.

[10] Milne, M.J. 1991. Accounting, environmental resource values, and non-market valuation techniques for environmental resources: A review, Accounting, Auditing \& Accountability Journal, 4(3), pp 81-109.

[11] Atkinson, G. 2000. Measuring Corporate Sustainability, Journal of Environmental Planning and Management, 43(2), pp 235-252.

[12] Bebbington, J., Gray, R., Hibbit, C. and Kirk, E. 2001. Full Cost Accounting: An agenda for action, Certified Accountants Educational Trust, London.

[13] Mathews, M.R. and Lockhart, J.A. 2001. The use of an environmental equity account to internalise externalities, Aston Business School Research Institute, RP0104, Birmingham.

[14] Carter, D.W., Perruso, L. and Lee, D.J. 2001. Full Cost Accounting in Environmental Decision-Making, University of Florida, http://edis.ifas.ufl.edu/FE310, accessed on 4 January 2006.

[15] American Institute of Chemical Engineers (AIChe). 2000. Total Cost Assessment methodology, Arthur D. Little report for the Center for Waste Reduction Technologies, http://www.aiche.org/cwrt/projects/cost.htm, accessed on 4 January 2006.

[16] World Bank. 2003. Environmental Assessment Sourcebook 1991 and Updates, Development topic: Environment, http://www.worldbank.org/, accessed on 4 January 2006

[17] Elkington, J. 1997. Cannibals with forks: The triple bottom line of $21^{\text {st }}$ century business, Capstone, London.

[18] Rennings, K. and Wiggering, H. 1997. Steps towards indicators of sustainable development: Linking economic and ecological concepts, Ecological Economics, 20, pp 25-36.

[19] Van Erck, R.P.G. 2003. Monetary evaluation of business sustainability. Case study: GTL fuel production in South Africa, Masters thesis, Department of Technology Management, Technical University Eindhoven \& Department of Engineering and Technology Management, University of Pretoria.

[20] Blignaut, J.N. 1995. Environmental Accounting in South Africa, Doctoral thesis, University of Pretoria.

[21] Van Pelt, M.J.F. 1993. Ecologically sustainable development and project appraisal in developing countries, Ecological Economics, 7, pp 19-42.

[22] Environmental Protection Agency (EPA). 1995. An introduction into Environmental Accounting as a Business Management Tool: Key Concepts and Terms, Office of Pollution Prevention and Toxics, EPA 742-R-95- 001, Washington DC.

[23] Spadaro, J.V. and Rabl, A. 2002. Air pollution damage estimates: The cost per kilogram of pollutant, International Journal of Risk Assessment and Management, 3(1), pp 75-97.

[24] Nationmaster. 2003. Statistical data retrieved from www.nationmaster.com, July 2003 
[25] Economic Intelligence Unit (EIU). 2004. EIU worldwide cost of living, http://eiu.enumerate.com/asp/wcol_WCOLHome.asp, accessed on 19 January 2004.

[26] Brent, A.C. and Hietkamp, S. 2003. Comparative evaluation of Life Cycle Impact Assessment methods with a South African case study, International Journal of Life Cycle Assessment, 8(1), pp 27-38.

[27] Van Pelt, M.J.F. 1993. Ecological sustainability and project appraisal, Aldershot, Avebury.

[28] Hartridge, O. and Pearce, D. 2001. Is UK Agriculture Sustainable? Environmentally Adjusted Economic Accounts For UK Agriculture, CSERGEEconomics, University College, London.

[29] Environmental Protection Agency (EPA). 1995. Health Effect Assessment Summary Table (HEAST), EPA/540/R-95/036, Washington DC.

[30] Rabl, A. and Eyre, N. 1998. An estimate of regional and global $\mathrm{O}_{3}$ damage costs from precursor $\mathrm{NO}_{\mathrm{X}}$ and VOC emissions, Environment International, 24, pp 835-388.

[31] European Commission. 1997. Maintenance, Improvement, Extension and Application of the ExternE Accounting Framework, Directorate-General XII, Brussels.

[32] Van Horen, C. 1996. The Cost of Power: Externalities in South Africa's Energy Sector, Doctoral thesis, University of Cape Town.

[33] Nieuwoudt, W. 2002. Water Market Institutions in South Africa: Lessons from Colorado, University Of Natal, Pietermaritzburg.

[34] Constanza, R., d’Arge, R., de Groot, R., Farber, S., Grasso, M., Hannon, B., Limburg, K., Naeem, S., O’Neill, R.V., Paruelo, J., Raskin, R.G., Sutton, P. and van der Belt, M. 1997. The Value of the World Ecosystem Services and Natural Capital, Nature, 387(15), pp 253-260.

[35] El Serafy, S. 1996. The proper calculation of income from depletable natural resources, In: Abroad, Y.J., El Serafy, A. and Lutz, E. Environmental Accounting for Sustainable Development, UNEP-World Bank, Washington DC. 